\title{
KARAKTERISTIK BUBUK ALGA COKLAT (Sargassum polycystum) PADA PERLAKUAN UKURAN BAHAN DAN SUHU PENGERINGAN
}

\author{
Shenni Maulina ${ }^{1}$, Lutfi Suhendra ${ }^{2}$, Ida Bagus Wayan Gunam ${ }^{2}$ \\ ${ }^{1}$ Mahasiswa Jurusan Teknologi Industri Pertanian, Fakultas Teknologi Pertanian, Unud \\ ${ }^{2}$ Dosen Jurusan Teknologi Industri Pertanian, Fakultas Teknologi Pertanian, Unud \\ Kampus Bukit Jimbaran, Badung-Bali \\ E-mail: shenny_maulina@yahoo.com ${ }^{1}$ \\ Email koresponden: lutfis@ unud.ac.id ${ }^{2}$
}

\begin{abstract}
One of the natural resources found in the sea and can be utilized is Sargassum polycystum. Sargassum polycystum has a pigment content one of which is fucosantin. Fucosantin can be utilized the field of health is as antioxidant. In addition, fucosantin is the most dominant brown and carotenoid dye present that can be used as natural dyes. The aim of this research were to know the effect of size pieces and drying temperature on the color quality and antioxidant of brown algae powder and to determine the best size pieces and drying temperature to obtain color quality and antioxidant of brown algae powder. The experiment in this study uses factorial Randomized Block Design (RBD) with two factors treatment, the first factor is the size pieces of 3 levels $2 \mathrm{~cm} \mathrm{x}$ $0.5 \mathrm{~cm}, 3 \mathrm{~cm} \times 0.5 \mathrm{~cm}, 4 \mathrm{~cm} \times 0.5 \mathrm{~cm}$ and the second factor is the temperature of the drying 3 levels $40 \pm 2^{\circ} \mathrm{C}$, $45 \pm 2{ }^{\circ} \mathrm{C}, 50 \pm 2^{\circ} \mathrm{C}$. The result showed that the size pieces effect on total phenol and antioxidant capacity of brown algae powder. The temperature of the drying effect on water content, total phenolic and antioxidant capacity of brown algae powder. The size pieces and temperature of the drying not effect on intensity of color $\left(\mathrm{L}^{*} \mathrm{a}^{*} \mathrm{~b}^{*}\right)$. The result of this research showed that pieces size $4 \mathrm{~cm} \mathrm{x} 0.5 \mathrm{~cm}$ and temperature of drying $45 \pm 2{ }^{\circ} \mathrm{C}$ produce the best characteristics water content $12.86 \pm 8.83 \%$, total phenolic $12.86 \pm 4.5 \mathrm{GAE} / 100 \mathrm{~g}$, antioxidant capacity $26.36 \pm 0.15 \mathrm{GAEAC} / 100 \mathrm{~g}$, intensity of brightness (L) $7.72 \pm 0.45$, intensity of redness (a) $-7.02 \pm 0.02$, yellowish intensity (b) $40.88 \pm 0.77$
\end{abstract}

Key words: Sargassum polycystum, Antioxidans Capacity, Total Phenol, Intensity of Color.

\section{PENDAHULUAN}

Indonesia merupakan negara kepulauan yang memiliki kurang lebih $70 \%$ laut yang kaya akan berbagai jenis sumber hayati (Winarno, 1990). Salah satu sumber daya alam yang terdapat di laut dan dapat dimanfaatkan adalah Sargassum polycystum. Alga jenis ini belum dibudidayakan secara optimal, seringkali Sargassum polycystum dianggap sebagai sampah di laut karena pada musim tertentu biasanya alga ini hanyut dan terdampar di pantai akibat ombak ataupun perubahan musim.

Sargassum polycystum memiliki kandungan pigmen salah satunya adalah fukosantin yang berwarna oranye. Fukosantin merupakan senyawa bioaktif yang mudah rusak oleh oksidasi, cahaya dan panas (Suhendra et al., 2014). Fukosantin memiliki banyak manfaat dibidang kesehatan yaitu sebagai antioksidan, anti peradangan dan anti obesitas (Maeda et al., 2005). Antioksidan adalah suatu senyawa yang dapat menghambat reaksi radikal bebas di dalam tubuh. Menurut Fithriani (2009) alga mengandung senyawa fenol yang berfungsi sebagai antioksidan.

Penelitian Djapiala et al. (2013) menunjukkan bahwa alga jenis Caulerpa racemosa memiliki kandungan total fenol yang tinggi yaitu sebesar 2624,62 mg GAE/g dibandingkan jenis Caulerpa sp. lainnya. Selain antioksidan alami, rumput laut coklat juga mengandung zat pigmen yang dapat dimanfaatkan sebagai alternatif pewarna alami yang dapat diaplikasikan ke dalam berbagai produk baik pangan maupun non pangan (Marwati, 2013). Warna dari rumput laut coklat Sargassum 
polycystum dipengaruhi oleh komposisi pigmen yang tersusun di dalamnya. Hasil penelitian Matsuno (2001) menyatakan bahwa fukosantin adalah zat warna coklat dan karotenoid utama paling dominan yang terdapat dalam rumput laut coklat ini.

Optimasi produk Sargassum polycystum dapat dilakukan dengan penanganan pasca panen secara optimal. Langkah dalam penanganan pasca panen adalah pengeringan. Tujuan dari pengeringan adalah mengurangi kandungan air dalam Sargassum sp., karena kualitas Sargassum sp. semakin baik dengan semakin rendah kadar airnya sampai batas 10\% (Hidayat, 2004). Hal tersebut bertujuan untuk mencegah tumbuhnya bakteri dan jamur pada tahap penyimpanan (Katno, 2008). Metode pengovenan memiliki kelebihan dibandingkan dengan metode kering angin dan sinar matahari antara lain suhu lebih stabil dan mudah dikendalikan (Chen et al., 1997).

Kecepatan pengeringan bahan dipengaruhi oleh pengecilan ukuran, baik dengan cara diiris atau dipotong. Proses pengecilan ukuran akan meningkatkan luas permukaan, sehingga menyebabkan air lebih mudah berdifusi atau menguap dari bahan pangan. Kecepatan penguapan air lebih cepat dan bahan menjadi lebih cepat kering (Mahardika, 2015). Penelitian Husni et al. (2014) melaporkan bahwa perlakuan suhu $50^{\circ} \mathrm{C}$ memiliki perlakuan terbaik pada rumput laut jenis Padina sp.

Penelitian mengenai pengaruh suhu pengeringan dan ukuran bahan terhadap kualitas warna dan antioksidan bubuk Sargassum polycystum masih jarang dipublikasikan. Oleh karena itu perlu diadakan penelitian yang lebih mendalam serta rinci mengenai hal tersebut. Tujuan penelitian ini yaitu untuk mengetahui pengaruh ukuran bahan dan suhu pengeringan terhadap kualitas warna dan antioksidan bubuk alga coklat (Sargassum polycystum) dan mendapatkan ukuran bahan dan suhu pengeringan yang terbaik guna menghasilkan kualitas warna dan antioksidan bubuk alga coklat (Sargassum polycystum).

\section{METODE PENELITIAN}

\section{Tempat dan Waktu}

Penelitian ini dilakukan di Laboratorium Pengolahan Pangan dan Analisis Pangan Fakultas Teknologi Pertanian Universitas Udayana. Waktu pelaksanaan mulai April hingga Juni 2017.

\section{Bahan dan Alat}

Peralatan yang digunakan dalam penelitian ini yaitu spektrofotometer (Genesys 10S UV-VIS), vortex (Barnstead Thermolyn Maxi Mix II), oven (Cole Parmer Stableterap), Erlenmeyer (Pyrex), botol sampel (Pyrex), tabung reaksi (Iwaki), kertas saring, aluminium foil, pisau, timbangan analitik (Shidmazu), pipet volume (Pyrex), pipet tetes, pipet mikro (Transferpette), labu ukur (Iwaki), gelas ukur (Iwaki), gelas beker (Pyrex), cawan porselin, kuvet, spatula, pinset, botol timbang, desikator, corong kaca (Pyrex), sentrifuse (Yenaco YC-1180T), blender (Electrolux), color reader (accuprobe tipe HH06), tissue, kertas label, baskom, nampan dan penggaris.

Bahan yang digunakan antara lain rumput laut Sargassum polycystum diperoleh di Pantai Sanur, Denpasar-Bali ( $8^{\circ} 68^{\prime} 42^{\prime \prime} \mathrm{S}$ dan $115^{\circ} 26^{\prime} 44^{\prime \prime}$ E) pada bulan Maret, metanol p.a (Merck), asam galat 
(Gallic acid monohydrate) (Sigma), akuades, folin-cioccalteu phenol (Merck), $\mathrm{Na}_{2} \mathrm{CO}_{3} 5 \%$ (Merck), 1,1-diphenyl-2-picrylhydrazil (DPPH) (Sigma).

\section{Rancangan Percobaan}

Percobaan ini menggunakan Rancangan Acak Kelompok (RAK) faktorial dengan dua faktor. Faktor pertama adalah ukuran bahan yaitu P1 $(2 \mathrm{~cm}$ x 0,5 cm), P2 $(3 \mathrm{~cm}$ x 0,5 cm), P3 $(4 \mathrm{~cm}$ x 0,5 $\mathrm{cm})$ dan faktor kedua adalah taraf suhu pengeringan yaitu T1 $\left(40 \pm 2^{\circ} \mathrm{C}\right), \mathrm{T} 2\left(45 \pm 2^{\circ} \mathrm{C}\right), \mathrm{T} 3\left(50 \pm 2^{\circ} \mathrm{C}\right)$. Selanjutnya perlakuan tersebut dikelompokkan menjadi 2 kelompok sehingga diperoleh 18 unit percobaan. Data obyektif dianalisis dengan sidik ragam dan dilanjutkan dengan uji Beda Nyata Jujur (BNJ). Perlakuan bubuk Sargassum polycystum terbaik ditentukan dengan menggunakan uji indeks efektivitas (De Garmo et al., 1984).

\section{Pelaksanaan Penelitian}

\section{Preparasi Bahan}

Rumput laut Sargassum polycystum segar yang diperoleh dari pantai Sanur dicuci dengan air bersih dan mengalir untuk menghilangkan sisa kotoran dan benda asing yang menempel. Rumput laut Sargassum polycystum dipotong dengan ukuran bahan $2 \mathrm{~cm} \times 0,5 \mathrm{~cm}, 3 \mathrm{~cm}$ x 0,5 cm, $4 \mathrm{~cm} \times 0,5 \mathrm{~cm}$.

\section{Pembuatan Bubuk}

Rumput laut yang telah dipotong sesuai ukuran dikeringkan menggunakan oven pengering selama \pm 4 jam pada suhu $40 \pm 2^{\circ} \mathrm{C}, 45 \pm 2^{\circ} \mathrm{C}, 50 \pm 2^{\circ} \mathrm{C}$ (Satriadi, 2015). Kemudian rumput laut yang telah dikeringkan dihancurkan dengan cara diblender hingga menjadi bubuk. Bubuk Sargassum polycystum yang diperoleh dimasukkan ke dalam plastik sampel.

\section{Parameter yang Diamati}

Parameter yang diamati pada penelitian ini meliputi : kadar air (Sudarmadji et al., 1997), total fenol (Julkunen-tiito, 1985), kapasitas antioksidan (Kubo et al.,2002) dan intensitas warna (Weaver, 1996).

\section{a. Kadar Air (Sudarmadji et al., 1997)}

Penentuan kadar air dilakukan dengan menggunakan metode pengeringan. Botol timbang yang digunakan dioven terlebih dahulu pada suhu $105^{\circ} \mathrm{C}$ selama 30 menit. Kemudian didinginkan dalam desikator selama \pm 15 menit dan ditimbang berat botol timbang kosong tersebut. Sampel kering yang berupa serbuk atau yang telah dihaluskan ditimbang sebanyak $3 \mathrm{~g}$ dalam botol timbang yang telah diketahui beratnya. Selanjutnya dikeringkan dalam oven pada suhu $105^{\circ} \mathrm{C}$ selama 4 jam. Kemudian didinginkan dalam desikator dan ditimbang. Setelah itu, dipanaskan kembali dalam oven pada suhu $105^{\circ} \mathrm{C}$ selama $1 \mathrm{jam}$, didinginkan dalam desikator, dan ditimbang kembali. Perlakuan ini dilakukan secara berulang hingga tercapai berat konstan (selisih berat $\pm 0,02 \mathrm{mg}$ ). Perhitungan kadar air yang digunakan adalah sebagai berikut:

$$
\text { Kadar air }(\%)=\frac{\text { berat awal }(\mathrm{g})-\text { berat akhir }(\mathrm{g})}{\text { berat awal }(\mathrm{g})} \times 100 \%
$$




\section{b. Total Fenol (Julkunen-Tiitto, 1985)}

Analisis kandungan total fenol dilakukan dengan tahapan pembuatan kurva standar dan analisis sampel.

\section{1) Pembuatan Kurva Standar}

Pembuatan kurva standar dibuat dengan konsentrasi asam galat $(0,01 \% \mathrm{~b} / \mathrm{v}$ dalam akuades $)$ masing-masing $0,10,20,40,60,80,100$ ppm dalam tabung reaksi. Kemudian ditambahkan akuades 0,$4 ; 0,36 ; 0,32 ; 0,24 ; 0,16 ; 0,08 ; 0 \mathrm{ml}$, Follin-cioccalteu phenol sebanyak 0,4 ml dan Natrium karbonat (5\% b/v dalam akuades) sebanyak 4,2 ml. Selanjutnya divortex dan didiamkan selama 30 menit, kemudian dibaca absorbansi kurva standar dengan spektofotometer pada panjang gelombang $760 \mathrm{~nm}$.

Penyiapan kurva standar bertujuan untuk menentukan nilai regresi linear sebagai rumus yang menjadi dasar untuk perhitungan total fenol pada sampel. Adapun rumus regresi linear yang diperoleh pada kurva standar asam galat adalah sebagai berikut: $y=a x+b$.

\section{2) Analisis Kadar Total Fenol pada Sampel}

Analisis total fenolik pada bubuk Sargassum polycystum menggunakan pereaksi Follincioccalteu phenol. Sampel ditimbang sebanyak 1,5 g kemudian dilarutkan ke dalam $5 \mathrm{ml}$ metanol 85\%. Sampel dengan konsentrasi $500 \mathrm{ppm}$ diambil sebanyak $0,4 \mathrm{ml}$ dan pereaksi Follin-ciaccalteu phenol sebanyak 0,4 ml. Setelah itu ditambahkan Natrium karbonat 5\% sebanyak 4,2 ml, divortex dan didiamkan selama 30 menit. Sampel kemudian dibaca absorbansinya dengan spektrofotometer pada panjang gelombang $760 \mathrm{~nm}$. Penentuan total fenol bubuk Sargassum polycystum dapat dihitung menggunakan rumus sebagai berikut :

$$
\text { Total Fenol }\left(\frac{\mathrm{mg} \mathrm{GAE}}{100 \mathrm{~g}}\right)=\frac{\chi\left(\frac{\mathrm{mg}}{1000 \mathrm{ml}}\right) \times \text { Volume larutan }(\mathrm{ml}) \times \mathrm{FP}}{\operatorname{sampel}(\mathrm{g})} \times 100
$$

Keterangan :

$\mathrm{X}=$ Konsentrasi yang diperoleh dari persamaan regresi linier

$\mathrm{FP} \quad=$ Faktor Pengencer

\section{c. Kapasitas Antioksidan (Kubo et al., 2002)}

Asam galat dibuat dengan konsentrasi 0, 5, 10, 15 dan 20 ppm. Sampel ditimbang sebanyak 0,5 $\mathrm{g}$, diencerkan menjadi $5 \mathrm{ml}$ dengan metanol, divortex, disaring sampai diperoleh filtrat. Filtrat dan standar dipipet hingga total volume menjadi $0,5 \mathrm{ml}$. Sampel dipipet $0,1 \mathrm{ml}$ ditambahkan 0,4 metanol lalu ditambahkan $25 \mathrm{ml}$ DPPH (1,1 diphenyl-2-picrylhydrazyl) pada tabung reaksi, kemudian dihomogenkan dengan vortex. Sampel diinkubasi selama 20 menit. Selanjutnya diukur absorbansinya pada panjang gelombang $517 \mathrm{~nm}$. Kapasitas antioksidan dihitung dengan menggunakan persamaan regresi linier $\mathrm{y}=\mathrm{ax}+\mathrm{b}$. Perhitungan kapasitas antioksidan dilakukan dengan 3 kali ulangan dan kapasitas antioksidan dinyatakan dengan kesetaraan pembanding baku mg GAEAC/100 g. 


\section{d. Intensitas Warna (Weaver, 1996)}

Analisis warna menurut (Weaver, 1996) dilakukan dengan color reader. Sampel ditempatkan dalam wadah plastik bening kemudian color reader dihidupkan dan tombol pembacaan diatur pada $\mathrm{L}$, a, b. L untuk parameter kecerahan (lightness), a dan b untuk koordinat kromatisitas. Tingkat kemerahan ditunjukkan oleh nilai a sedangkan tingkat kekuningan ditunjukkan oleh nilai b. Intensitas warna diukur dengan menekan tombol target.

\section{HASIL DAN PEMBAHASAN}

\section{Kadar Air}

Hasil analisis ragam menunjukkan bahwa ukuran bahan berpengaruh tidak nyata $(\mathrm{P}>0,05)$, suhu pengeringan berpengaruh nyata $(\mathrm{P}<0,05)$, serta interaksi keduanya berpengaruh tidak nyata $(\mathrm{P}>0,05)$ terhadap kadar air bubuk alga coklat. Nilai rata-rata kadar air bubuk alga coklat dapat dilihat pada Tabel 1.

Tabel 1. Nilai rata-rata kadar air bubuk alga coklat (\%)

\begin{tabular}{cllll}
\hline Ukuran bahan & \multicolumn{3}{c}{ Suhu pengeringan $\left({ }^{\circ} \mathrm{C}\right)$} & \multirow{2}{*}{ Rata-rata } \\
\cline { 2 - 4 }$(\mathrm{cm})$ & \multicolumn{1}{c}{$40( \pm 2)$} & $45( \pm 2)$ & $50( \pm 2)$ & \\
\hline $2 \times 0,5$ & $8,29 \pm 3,27$ & $9,53 \pm 2,38$ & $6,81 \pm 1,3$ & $8,21 \pm 2,31^{\mathrm{a}}$ \\
$3 \times 0,5$ & $13,14 \pm 6,51$ & $11,23 \pm 2,52$ & $6,60 \pm 3,9$ & $10,32 \pm 4,31^{\mathrm{a}}$ \\
$4 \times 0,5$ & $13,99 \pm 6,01$ & $12,86 \pm 8,83$ & $6,48 \pm 2,3$ & $11,11 \pm 5,71^{\mathrm{a}}$ \\
\hline Rata-rata & $11,80 \pm 5,26^{\mathrm{a}}$ & $11,20 \pm 4,57^{\mathrm{a}}$ & $6,63 \pm 2,5^{\mathrm{b}}$ & \\
\hline
\end{tabular}

Keterangan: Huruf beda di belakang nilai rata-rata pada kolom dan baris yang sama menunjukkan perbedaan yang nyata $(\mathrm{P}<0,05)$

Berdasarkan data penelitian di atas, diketahui bahwa perlakuan ukuran bahan $4 \mathrm{~cm} \times 0,5 \mathrm{~cm}$ menghasilkan kadar air yang lebih tinggi yaitu $13,99 \pm 6,01 \%$, sedangkan perlakuan ukuran bahan 4 $\mathrm{cm} \times 0,5 \mathrm{~cm}$ dan suhu pengeringan $50 \pm 2{ }^{\circ} \mathrm{C}$ menghasilkan kadar air yang lebih rendah yaitu $6,48 \pm 2,3 \%$. Besar kadar air dalam suatu bahan tidak dapat dipengaruhi oleh ukuran bahan, ukuran bahan $2 \mathrm{~cm} \times 0,5 \mathrm{~cm}, 3 \mathrm{~cm} \times 0,5 \mathrm{~cm}$, dan $4 \mathrm{~cm} \times 0,5 \mathrm{~cm}$ menunjukkan perbedaan yang tidak nyata karena perlakuan potongan ukuran bahan tidak mengubah kadar air dari bubuk alga coklat. Hal ini kemungkinan disebabkan batang dan daun alga cenderung tidak padat yang terdiri beberapa sel, sehingga air akan lebih mudah menguap dan tidak dipengaruhi oleh ukuran pengecilan bahan. Penelitian ini sesuai dengan pernyataan Sukamulyo (1989), bahwa kadar air tidak dipengaruhi oleh perlakuan ukuran potong bahan tetapi oleh cara pengeringan dan intensitas cahaya matahari.

Suhu pengeringan berpengaruh terhadap kandungan kadar air bubuk alga coklat. Hal ini menunjukkan perbedaan yang nyata pada perlakuan suhu $40 \pm 2^{\circ} \mathrm{C}, 45 \pm 2^{\circ} \mathrm{C}$ dan $50 \pm 2^{\circ} \mathrm{C}$. Kadar air menurun seiring dengan meningkatnya suhu yang diberikan. Hal ini kemungkinan disebabkan oleh pemanasan semakin tinggi mengakibatkan gerakan partikel air dalam bahan semakin cepat sehingga menyebabkan air lebih cepat menguap. Pernyataan tersebut sesuai dengan Winarsih (2007) yang menyatakan bahwa pengeringan dengan suhu yang lebih tinggi mempengaruhi air dalam bahan dan semakin singkat waktu yang dibutuhkan untuk menjadikan kadar air yang lebih rendah. 


\section{Total Fenol}

Hasil analisis ragam menunjukkan bahwa ukuran bahan berpengaruh nyata $(\mathrm{P}<0,05)$ dan suhu pengeringan berpengaruh sangat nyata $(\mathrm{P}<0,01)$, sedangkan interaksi keduanya berpengaruh tidak nyata $(\mathrm{P}>0,05)$ terhadap total fenol. Nilai rata-rata total fenol dari bubuk alga coklat dapat dilihat pada Tabel 2.

Tabel 2. Nilai rata-rata total fenol bubuk alga coklat (mgGAE/100g)

\begin{tabular}{cllll}
\hline \multirow{2}{*}{$\begin{array}{c}\text { Ukuran bahan } \\
(\mathrm{cm})\end{array}$} & \multicolumn{3}{c}{ Suhu pengeringan $\left({ }^{\circ} \mathrm{C}\right)$} & \multirow{2}{*}{ Rata-rata } \\
\cline { 2 - 4 } & \multicolumn{1}{c}{$40( \pm 2)$} & \multicolumn{1}{c}{$45( \pm 2)$} & $50( \pm 2)$ & \\
\hline $2 \times 0,5$ & $9,54 \pm 1,5$ & $10,03 \pm 1,67$ & $7,51 \pm 0,3$ & $9,02 \pm 1,15^{\mathrm{a}}$ \\
$3 \times 0,5$ & $14,14 \pm 5,1$ & $11,73 \pm 1,81$ & $7,98 \pm 0,4$ & $11,28 \pm 7,31^{\mathrm{ab}}$ \\
$4 \times 0,5$ & $15,99 \pm 1,77$ & $12,86 \pm 4,5$ & $7,60 \pm 0,9$ & $12,15 \pm 2,39^{\mathrm{b}}$ \\
\hline Rata-rata & $13,22 \pm 2,79^{\mathrm{a}}$ & $11,54 \pm 2,66^{\mathrm{a}}$ & $7,69 \pm 0,52^{\mathrm{b}}$ & \\
\hline
\end{tabular}

Keterangan: Huruf beda di belakang nilai rata-rata pada kolom dan baris yang sama menunjukkan perbedaan yang nyata $(\mathrm{P}<0,05)$

Berdasarkan data penelitian di atas, diketahui bahwa perlakuan ukuran bahan $4 \mathrm{~cm} \times 0,5 \mathrm{~cm}$ dan suhu pengeringan $40 \pm 2^{\circ} \mathrm{C}$ menghasilkan total fenol yang lebih tinggi yaitu $15,99 \pm 1,77 \mathrm{mgGAE} / 100 \mathrm{~g}$, sedangkan perlakuan ukuran bahan $2 \mathrm{~cm} \times 0,5 \mathrm{~cm}$ dan suhu pengeringan $50 \pm 2^{\circ} \mathrm{C}$ menghasilkan total

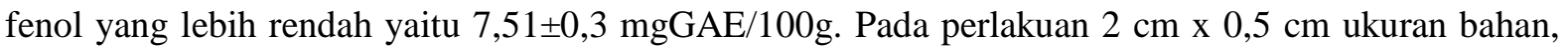
nilai senyawa fenol semakin rendah dengan semakin kecilnya ukuran bahan. Hal ini kemungkinan disebabkan oleh adanya pengecilan ukuran yang akan merusak sel. Semakin kecil ukuran bahan, sel yang rusak akan lebih banyak, sehingga akan memudahkan saat ekstraksi fenol dari bahan.

Pada perlakuan suhu pengeringan $40 \pm 2^{\circ} \mathrm{C}$, semakin rendah suhu yang digunakan akan menghasilkan total fenol yang tinggi, dan begitu juga sebaliknya. Pernyataan tersebut sesuai dengan Ibrahim (2015) menyatakan bahwa fenol memiliki sifat yang mudah teroksidasi dan sensitif terhadap perlakuan panas. Dengan demikian suhu pengeringan yang rendah akan menghasilkan nilai rata-rata total fenol tertinggi. Sebaliknya dengan suhu yang tinggi akan menghasilkan nilai rata-rata total fenol terendah. Hal ini menyebabkan ada hubungan antara suhu dan senyawa fenol, kandungan senyawa fenol menurun seiring dengan peningkatan suhu yang lebih tinggi.

\section{Kapasitas Antioksidan}

Hasil analisis ragam menunjukkan bahwa ukuran bahan dan suhu pengeringan serta interaksi berpengaruh sangat nyata $(\mathrm{P}<0,01)$ terhadap kapasitas antioksidan. Nilai rata-rata kapasitas antioksidan dari bubuk alga coklat dapat dilihat pada Tabel 3.

Tabel 3. Nilai rata-rata kapasitas antioksidan pada bubuk alga coklat (mgGAEAC/100g)

\begin{tabular}{cccc}
\hline Ukuran bahan & \multicolumn{3}{c}{ Suhu pengeringan(C) } \\
\cline { 2 - 4 }$(\mathrm{cm})$ & \multicolumn{1}{c}{$40( \pm 2)$} & $45( \pm 2)$ & $50( \pm 2)$ \\
\hline $2 \times 0,5$ & $17,67 \pm 0,91^{\mathrm{e}}$ & $20,64 \pm 0,66^{\mathrm{cd}}$ & $19,05 \pm 0,07^{\mathrm{de}}$ \\
$3 \times 0,5$ & $14,06 \pm 0,80^{\mathrm{f}}$ & $21,63 \pm 0,62^{\mathrm{c}}$ & $21,93 \pm 0,14^{\mathrm{c}}$ \\
$4 \times 0,5$ & $25,26 \pm 0,27^{\mathrm{ab}}$ & $26,36 \pm 0,15^{\mathrm{a}}$ & $24 \pm 0,07^{\mathrm{b}}$ \\
\hline
\end{tabular}

Keterangan: Huruf beda dibelakang nilai rata-rata pada kolom dan baris yang sama menunjukkan perbedaan yang sangat nyata $(\mathrm{P}<0,01)$ 
Berdasarkan data penelitian di atas, diketahui bahwa ukuran bahan dan suhu pengeringan sangat berpengaruh terhadap kapasitas antioksidan dari bubuk alga coklat. Perlakuan ukuran bahan $4 \mathrm{~cm} \mathrm{x}$ $0,5 \mathrm{~cm}$ dan suhu pengeringan $45 \pm 2^{\circ} \mathrm{C}$ menghasilkan kapasitas antioksidan tertinggi yaitu sebesar 26,36 $\pm 0,15 \mathrm{mgGAEAC} / 100 \mathrm{~g}$. Kapasitas antioksidan semakin meningkat dengan semakin besarnya ukuran bahan. Hal ini diduga karena semakin besar ukuran bahan maka semakin sedikit senyawa yang yang bersifat antioksidan rusak akibat suhu pengeringan.

Suhu pengeringan juga berpengaruh dalam menghasilkan kapasitas antioksidan yang baik. Pada suhu pengeringan yang tinggi senyawa antioksidan yang berfungsi pada bubuk alga coklat akan mengalami kerusakan, sedangkan sebaliknya, apabila suhu pengeringan yang rendah akan mendapatkan senyawa antioksidan yang baik. Sandrasari (2008), menyatakan bahwa suatu senyawa yang mempunyai kapasitas antioksidan sangat kuat jika menghambat perkembangan radikal bebas lebih dari $80 \%$, sedang jika menghambat sebesar 50-80\%, dan lemah jika memiliki penghambatan kurang dari $50 \%$.

\section{Intensitas Warna}

Hasil analisis ragam menunjukkan bahwa ukuran bahan, suhu pengeringan serta interaksi berpengaruh tidak nyata $(\mathrm{P}>0,05)$ terhadap nilai $\mathrm{L}^{*} \mathrm{a}^{*}$ dan $\mathrm{b}^{*}$. Nilai $\mathrm{L}^{*}$ (tingkat kecerahan) menyatakan tingkat gelap sampai terang dengan kisaran 0-100. Nilai $a^{*}$ (tingkat kemerahan) menyatakan tingkat warna hijau sampai merah dengan kisaraan nilai -100 sampai +100 . Nilai $b^{*}$ (tingkat kekuningan) menyatakan tingkat warna biru sampai kuning kisaran nilai -100 sampai +100 .

Tabel 4. Nilai rata-rata $L^{*}$ pada bubuk alga coklat

\begin{tabular}{ccccc}
\hline \multirow{2}{*}{$\begin{array}{c}\text { Ukuran bahan } \\
\text { (cm) }\end{array}$} & \multicolumn{3}{c}{ Suhu pengeringan $\left({ }^{\circ} \mathrm{C}\right)$} & Rata-rata \\
\cline { 2 - 4 } & $40( \pm 2)$ & $45( \pm 2)$ & $50( \pm 2)$ & \\
\hline $2 \times 0,5$ & $13,56 \pm 2,36$ & $12,02 \pm 0,18$ & $13,19 \pm 1,12$ & $12,92 \pm 1.22^{\mathrm{a}}$ \\
$3 \times 0,5$ & $12,3 \pm 10,38$ & $16,55 \pm 3,36$ & $16,63 \pm 7,00$ & $15,16 \pm 6,91^{\mathrm{a}}$ \\
$4 \times 0,5$ & $16,47 \pm 2,29$ & $7,72 \pm 0,45$ & $16,07 \pm 1,24$ & $13,42 \pm 1,32^{\mathrm{a}}$ \\
\hline Rata-rata & $14,11 \pm 5,01^{\mathrm{a}}$ & $12,09 \pm 1,33^{\mathrm{a}}$ & $15,29 \pm 3,12^{\mathrm{a}}$ & \\
\hline
\end{tabular}

Keterangan : Huruf yang sama di belakang nilai rata-rata pada baris dan kolom yang sama menunjukkan perbedaan yang tidak nyata $(\mathrm{P}<0,05)$

Tabel 4. menunjukkan nilai rata-rata $L^{*}$ (tingkat kecerahan) yang berkisar antara 12,09 hingga 15,29. Nilai $\mathrm{L}^{*}$ menunjukkan kecenderungan warna terang dari gelap sampai terang. semakin besar nilai $\mathrm{L}^{*}$ menunjukkan warna yang semakin terang.

Tabel 5. Nilai rata-rata $a^{*}$ pada bubuk alga coklat

\begin{tabular}{ccccc}
\hline \multirow{2}{*}{$\begin{array}{c}\text { Ukuran bahan } \\
(\mathrm{cm})\end{array}$} & \multicolumn{3}{c}{ Suhu pengeringan $\left({ }^{\circ} \mathrm{C}\right)$} & \multirow{2}{*}{ Rata-rata } \\
\cline { 2 - 4 } & $40( \pm 2)$ & $45( \pm 2)$ & $50( \pm 2)$ & \\
\hline $2 \times 0,5$ & $-5,34 \pm 0,10$ & $-4,06 \pm 0,01$ & $-6,35 \pm 0,01$ & $-5,25 \pm 0,04^{\mathrm{a}}$ \\
$3 \times 0,5$ & $-5,33 \pm 0,03$ & $-5,44 \pm 0,02$ & $-4,09 \pm 5,15$ & $-4,95 \pm 1,73^{\mathrm{a}}$ \\
$4 \times 0,5$ & $-8,46 \pm 0,001$ & $-7,02 \pm 0,02$ & $-7,05 \pm 0,58$ & $-7,51 \pm 0,20^{\mathrm{a}}$ \\
\hline Rata-rata & $-6,37 \pm 0,04^{\mathrm{a}}$ & $-5,51 \pm 0,01^{\mathrm{a}}$ & $-5,83 \pm 1,91^{\mathrm{a}}$ & \\
\hline
\end{tabular}

Keterangan : Huruf yang sama di belakang nilai rata-rata pada baris dan kolom yang sama menunjukkan perbedaan yang tidak nyata $(\mathrm{P}<0,05)$ 
Tabel 5. menunjukkan nilai rata-rata $a^{*}$ (tingkat kehijauan) yang berkisar antara $-7,51 \pm 0,20$ hingga $-4,95 \pm 1,73$. Nilai a* menunjukkan kecenderungan warna hijau dari hijau sampai merah. semakin kecil nilai a* menunjukkan warna yang semakin hijau.

Tabel 6. Nilai rata-rata $b^{*}$ pada bubuk alga coklat

\begin{tabular}{crrrr}
\hline \multirow{2}{*}{$\begin{array}{c}\text { Ukuran bahan } \\
(\mathrm{cm})\end{array}$} & \multicolumn{3}{c}{ Suhu pengeringan $(\mathrm{C})$} & Rata-rata \\
\cline { 2 - 4 } & \multicolumn{1}{c}{$40( \pm 2)$} & \multicolumn{1}{c}{$45( \pm 2)$} & \multicolumn{1}{c}{$50( \pm 2)$} & \\
\hline 2 × 0,5 & $36,56 \pm 16,29$ & $37,66 \pm 15,36$ & $24,99 \pm 1,59$ & $33,07 \pm 11,08^{\mathrm{a}}$ \\
3 x 0,5 & $29,79 \pm 7,85$ & $28,29 \pm 2,07$ & $28,03 \pm 2,25$ & $28,70 \pm 4,05^{\mathrm{a}}$ \\
4 x 0,5 & $12,65 \pm 1,98$ & $40,88 \pm 0,77$ & $29,28 \pm 3,50$ & $27,60 \pm 2,08^{\mathrm{a}}$ \\
\hline rata-rata & $26,33 \pm 8,70^{\mathrm{a}}$ & $35,61 \pm 6,06^{\mathrm{a}}$ & $27,43 \pm 2,44^{\mathrm{a}}$ & \\
\hline
\end{tabular}

Keterangan : Huruf yang sama di belakang nilai rata-rata pada baris dan kolom yang sama menunjukkan perbedaan yang tidak nyata $(\mathrm{P}<0,05)$

Tabel 6. menunjukkan nilai rata-rata $b^{*}$ (tingkat kekuningan) yang berkisar antara $26,33 \pm 8,70$ hingga $35,61 \pm 6,06$. Nilai $b^{*}$ menunjukkan kecenderungan warna kuning dari biru sampai kuning. semakin besar nilai $b^{*}$ menunjukkan warna yang semakin kuning.

\section{Hasil Uji Indeks Efektivitas Bubuk Alga Coklat}

Uji indeks efektivitas bertujuan untuk menentukan perlakuan terbaik dalam menghasilkan bubuk Sargassum polycystum. Perlakuan terbaik ditunjukkan dengan jumlah nilai hasil tertinggi dan dapat dilihat pada Tabel 7. yang menunjukkan bahwa perlakuan ukuran bahan P3T2 yaitu $4 \mathrm{~cm} \times 0,5 \mathrm{~cm}$ dan suhu pengeringan $45 \pm 2^{\circ} \mathrm{C}$ mempunyai nilai tertinggi yaitu 0,87 . Hal ini disebabkan oleh suhu pengeringan yang rendah dapat menghasilkan kualitas bubuk Sargassum polycystum yang terbaik, karena apabila pada proses pemanasan memakai suhu pengeringan yang tinggi akan merusak senyawa bioaktif yang terkandung dalam bubuk Sargassum polycystum.

Tabel 7. Hasil uji efektivitas untuk menentukan perlakuan terbaik bubuk alga coklat

\begin{tabular}{|c|c|c|c|c|c|c|c|c|}
\hline Variabel & & kadar air & $\begin{array}{c}\text { intensitas } \\
\text { warna } \\
\left(\mathrm{L}^{*}\right)\end{array}$ & $\begin{array}{l}\text { intensitas } \\
\text { warna }\left(\mathrm{a}^{*}\right)\end{array}$ & $\begin{array}{c}\text { intensitas } \\
\text { warna }\left(b^{*}\right)\end{array}$ & $\begin{array}{l}\text { total } \\
\text { fenol }\end{array}$ & $\begin{array}{l}\text { kapasitas } \\
\text { antioksidan }\end{array}$ & jumlah \\
\hline & (BV) & 0,17 & 0,40 & 0,43 & 0,67 & 0,83 & 1,00 & 3,50 \\
\hline & $(\mathrm{BN})$ & 0,05 & 0,11 & 0,12 & 0,19 & 0,24 & 0,29 & 1,00 \\
\hline \multirow[t]{2}{*}{ P1T1 } & $\mathrm{Ne}$ & 0,76 & 0,34 & 0,98 & 0,85 & 0,24 & 0,29 & \\
\hline & $\mathrm{Nh}$ & 0,04 & 0,04 & 0,12 & 0,16 & 0,06 & 0,08 & 0,50 \\
\hline \multirow[t]{2}{*}{ P2T1 } & $\mathrm{Ne}$ & 0,11 & 0,49 & 0,99 & 0,61 & 0,78 & 0,00 & \\
\hline & $\mathrm{Nh}$ & 0,01 & 0,06 & 0,12 & 0,12 & 0,19 & 0,00 & 0,49 \\
\hline \multirow[t]{2}{*}{ P3T1 } & $\mathrm{Ne}$ & 0,00 & 0,02 & 1,00 & 0,00 & 1,00 & 0,91 & \\
\hline & $\mathrm{Nh}$ & 0,00 & 0,00 & 0,12 & 0,00 & 0,24 & 0,26 & 0,62 \\
\hline \multirow[t]{2}{*}{ P1T2 } & $\mathrm{Ne}$ & 0,59 & 0,52 & 0,99 & 0,89 & 0,30 & 0,53 & \\
\hline & $\mathrm{Nh}$ & 0,03 & 0,06 & 0,12 & 0,17 & 0,07 & 0,15 & 0,60 \\
\hline \multirow[t]{2}{*}{ P2T2 } & $\mathrm{Ne}$ & 0,37 & 0,01 & 0,99 & 0,55 & 0,50 & 0,62 & \\
\hline & $\mathrm{Nh}$ & 0,02 & 0,00 & 0,12 & 0,11 & 0,12 & 0,18 & 0,54 \\
\hline \multirow[t]{2}{*}{ P3T2 } & $\mathrm{Ne}$ & 0,15 & 1,00 & 1,00 & 1,00 & 0,63 & 1,00 & \\
\hline & $\mathrm{Nh}$ & 0,01 & 0,11 & 0,12 & 0,19 & 0,15 & 0,29 & $\mathbf{0 , 8 7}$ \\
\hline \multirow[t]{2}{*}{ P1T3 } & $\mathrm{Ne}$ & 0,96 & 0,39 & 1,00 & 0,44 & 0,00 & 0,41 & \\
\hline & $\mathrm{Nh}$ & 0,05 & 0,04 & 0,12 & 0,08 & 0,00 & 0,12 & 0,41 \\
\hline \multirow[t]{2}{*}{ P2T3 } & $\mathrm{Ne}$ & 1,00 & 0,00 & 0,00 & 0,54 & 0,05 & 0,64 & \\
\hline & $\mathrm{Nh}$ & 0,05 & 0,00 & 0,00 & 0,10 & 0,01 & 0,18 & 0,35 \\
\hline \multirow{2}{*}{ P3T3 } & $\mathrm{Ne}$ & 0,98 & 0,06 & 0,87 & 0,59 & 0,01 & 0,81 & \\
\hline & $\mathrm{Nh}$ & 0,05 & 0,01 & 0,11 & 0,11 & 0,00 & 0,23 & 0,51 \\
\hline
\end{tabular}


Keterangan : $\mathrm{P} 1=$ ukuran bahan $2 \mathrm{~cm} \times 0,5 \mathrm{~cm}$ $\mathrm{P} 2=$ ukuran bahan $3 \mathrm{~cm} \times 0,5 \mathrm{~cm}$ $\mathrm{P} 3=$ ukuran bahan $4 \mathrm{~cm} \times 0,5 \mathrm{~cm}$
$\mathrm{T} 1=$ suhu pengeringan $40 \pm 2^{\circ} \mathrm{C}$

$\mathrm{T} 2=$ suhu pengeringan $45 \pm 2^{\circ} \mathrm{C}$

$\mathrm{T} 3=$ suhu pengeringan $50 \pm 2^{\circ} \mathrm{C}$

\section{KESIMPULAN DAN SARAN}

\section{Kesimpulan}

1. Ukuran bahan berpengaruh terhadap total fenol dan kapasitas antioksidan dari bubuk alga coklat (Sargassum polycystum). Suhu pengeringan sangat berpengaruh terhadap kadar air, total fenol dan kapasitas antioksidan dari bubuk alga coklat (Sargassum polycystum). Ukuran bahan dan suhu pengeringan tidak mempengaruhi intensitas warna $\left(\mathrm{L}^{*}, \mathrm{a}^{*}, \mathrm{~b}^{*}\right)$ dari bubuk alga coklat (Sargassum polycystum). Interaksi ukuran bahan dan suhu pengeringan berpengaruh sangat nyata terhadap kapasitas antioksidan bubuk alga coklat (Sargassum polycystum).

2. Perlakuan terbaik untuk menghasilkan bubuk alga coklat yaitu pada perlakuan ukuran bahan 4 $\mathrm{cm} \times 0,5 \mathrm{~cm}$ dan suhu pengeringan $45 \pm 2^{\circ} \mathrm{C}$ dengan karakteristik kadar air $12,86 \pm 8,83 \%$, total fenol 12,86 $\pm 4,5$ GAE/100g, kapasitas antioksidan 26,36 $\pm 0,15$ GAEAC/100g, intensitas kecerahan (L) 7,72 $\pm 0,45$, intensitas kemerahan (a) $-7,02 \pm 0,02$, intensitas kekuningan (b) $40,88 \pm 0,77$.

\section{Saran}

Perlu adanya penelitian lebih lanjut mengenai pengaruh metode pengeringan terhadap bubuk alga coklat (Sargassum polycystum) yang dapat memungkinkan hasil yang lebih baik lagi.

\section{DAFTAR PUSTAKA}

Chen, J.C., P.C.K. Cheung dan P.O. Ang. 1997. Comparative studies on the effect of three drying method on nutritional composition of seaweed Sargassum hemiphyllum (Turn). Journal of Agriculture and Food Chemistry. 45(8): 3056-3059.

De Garmo, E.P., W. G. Sullivan and C.R. Canada. 1984. Engineering Economy. $7^{\text {th }}$ Edition. Mac. Millan Publ Co. New York.

Djapiala F.Y., L. ADY Montolalu., dan F. Mentang. 2013. Kandungan total fenol dalam rumput laut Caulerpa racemosa yang berpotensi sebagai antioksidan. Fakultas Perikanan dan Ilmu Kelautan Unsrat.

Firdaus, M., M. Astawan, D. Muchtadi, T.Wresdiyanti, S.Waspadji, K. Karyono Setyawati. 2012. Toksisitas akut ekstrak methanol rumput laut coklat Sargassum echinocarphum. JPHPI. 15 (2) :23-24.

Hidayat, A. 2004. Pengaruh Kelembaban Udara Terhadap Kualitas Rumput Laut Kering Asin Jenis Eucheuma cottoni dan Gracillaria sp. Selama Penyimpanan. Skripsi. Tidak dipublikasikan. Fakultas Perikanan dan Ilmu Kelautan. Institut Pertanian Bogor, Bogor.

Husni, A. 2014. Aktivitas antioksidan Padina sp. pada berbagai suhu dan lama pengeringan. 9(2) : $165-173$

Ibrahim A.M., F.H. Yunianta, dan Sriherfyna. 2015. Pengaruh suhu dan lama waktu ekstraksi terhadap sifat kimia dan fisik pada pembuatan minuman sari jahe merah Zingiber officinale var. Rubrum dengan kombinasi penambahan madu sebagai pemanis. Jurnal Pangan dan Agroindustri. 3(2):530-541. 
Julkunen-Tiitto, R. 1985. Phenolic Consctituens in the leaves of Northern Willows: Methods for the Analysis of Certain Phenolics. J. Agric. Food Chem. 33: 213-217.

Katno. 2008. Tingkat Manfaat, Keamanan dan Efektivitas Tanaman Obat dan Obat Tradisional. Balai Besar Penelitian dan Pengembangan Tanaman Obat dan Obat Tradisional. Jawa Tengah.

Kubo, I., Masuda, Xiao, and Haraguchi. 2002. Antioxidant activity of deodecyl gallate. J. Agric. Food Chem. 50: 3533-3539.

Maeda, H., M. Hosokawa, T. Sashima, K. Funayama and K. Miyashita. 2005. Fukoxanthin from edible seaweed Undaria pinnatifida shows antiobesity affect through UCP1 expression in white adipose tissues. Biochemical and biophysical research communication. 32: 392-397.

Mahardika, L.P. 2015. Rancang Bangunan Alat Pengering Tipe Tray Dengan Media Udara Panas Ditinjau Dari Lama Waktu Pengeringan Terhadap Energi Pada Alat Heat Exchanger. Skripsi. Tidak Dipublikasikan. Teknik Kimia Politeknik Negeri Srwijaya, Palembang.

Marwati, S. 2013. Pembuatan pewarna alami makanan dan aplikasinya. Jurusan Pendidikan Kimia, Universitas Negeri Yogyakarta, Yogyakarta.

Matsuno, T. 2001. Aquatic animal carotenoids. Fisheries Science. 67: 771-783.

Sandrasari, D.A., 2008. Kapasitas Antioksidan dan Hubungannya dengan Nilai Total Fenol Ekstrak Sayuran Indigenous. Tesis S2. Tidak dipublikasikan. Sekolah Pascasarjana Institute Pertanian Bogor, Bogor.

Satriadi, I.W.A. 2015. Pengaruh Suhu dan Ukuran Potongan Terhadap Karakteristik Teh Kulit Lidah Buaya (Aloe barbadensis milleer). Skripsi. Tidak Dipublikasikan. Universitas Udayana. Bukit Jimbaran.

Sudarmadji, S., B. Haryono, dan Suhardi. 1989. Prosedur Analisa untuk Bahan Makanan dan Pertanian. Penerbit Liberty, Yogyakarta.

Suhendra, L., S. Raharjo, P. Hastuti, dan C. Hidayat. 2014. Stabilitas mikroemulsi fucoxanthin dan efektivitasnya dalam menghambat foto oksidasi vitamin C pada Model Minuman. Agritech. 34(2) : 139-145.

Sukamulyo, S. 1989. Mempelajari cara ekstraksi dengan praperlakuan asam dalam pembuatan agar dari Gelidium sp. Skripsi. Tidak dipublikasikan. Fakultas Teknologi Pertanian IPB. Bogor.

Weaver, C. 1996. The Food Chemistry Laboratory. CRC Press, Boca Raton, New York, london, Tokyo.

Winarno, F.G. 1990. Teknologi Pengolahan Rumput Laut : Pustaka Sinar Harapan, Jakarta.

Winarsih, H. 2007. Antioksidan Alami dan Radikal Bebas Potensi dan Aplikasi Dalam Kesehatan. Kanisius, Yogyakarta. 